\title{
LEARNING THROUGH TEACHING AND SHARING IN THE JIGSAW CLASSROOM
}

A.M. Norintan. Learning through teaching and sharing in the jigsaw classroom Annal Dent Univ Malaya 2008; 15(2): 71-76.

\section{ABSTRACT}

Teaching is a complex activity which consists not only of giving instructions but also promotion of learning. Different students have different preference for learning styles. Dental educators must therefore attempt to mix and match their methods of teaching to accommodate students with differing learning styles to provide an opportunity to maximize their learning. This paper aims to share the writer's experience and students' perceptions towards a different mode of teaching/learning method. The Jigsaw Classroom method was employed on University of Malaya's third-year dental students during their Water Fluoridation lecture. At the end of the session, students were asked to reflect upon the learning experience and to inscribe their feelings. Initially, students showed their resentment towards the new learning style but their resistance changed once they got into a group and started to learn from each other. In the reflective essay, most students expressed that learning through teaching and discussing as required in the Jigsaw method enhanced their understanding of the topic and they claimed that they were able to retain the information better. In this study, the Jigsaw method proved that learning in the lecture hall can be fun, educational and enriching.

Key words: jigsaw classroom, teaching and learning method

\section{INTRODUCTION}

Most students learn:

$10 \%$ of what they read

$20 \%$ of what they hear

$30 \%$ of what they see

$50 \%$ of what they see and hear

$70 \%$ of what they talk over with others

$80 \%$ of what they use and do in real life

$95 \%$ of what they teach someone else

Although the above quotation has been assumed to be fraudulent, and has been accused of being crafted by many different authors who have presented many different configurations, one's experience as a learner and teacher would tell them that is indeed right.
Original Article

A.M. Norintan
Department of Community Dentistry,
Faculty of Dentistry,
University of Malaya,
50603 Kuala Lumpur,
Malaysia.
Tel: +603-79674866
Email: norintan@um.edu.my
Corresponding author: Norintan Ab. Murat

Times are changing and students now are different from decades ago. However, university teaching remains the same as the majority of teaching methods are still confined to giving lectures - or in other words, "telling stories". Lecturing is essentially a passive learning method that encourages rote memorisation and note-taking as the means of assimilating knowledge (1). In medical education, the reason why lecturing is still the predominant format in classes (2) could be because there are increased demands for clinical time, which lead to decreased time available for teaching (3). The usually short slot for teaching is one explanation why medical or dental teachers opt for lecturing, as they need to cover a large body of complex subject matter in a short period of time. This is above the need to create engaging activities to ensure that students truly retain the information they receive.

With the explosion in knowledge and the advancement in teachnology requiring rapid information transfer, it is no longer possible to teach and update knowledge and information through lectures. Students need to take responsibility for their own learning. Although it hasx been pointed out that medical and dental professions are often taught by expert clinicians, who for the most part have limited or no prior teaching training (4) and teach in the same way that they were taught (3), this does not excuse lecturers for being complacent. Lecturers need to be creative and understand that there are many ways in which a student learns. They must update their pedagogical methodologies to help promote active learning among students. The future of local dental professions depends very much upon the upbringing of dental students in dental schools.

Each learner has a particular preferences for learning style. The educational literature suggests that attending to learning style can improve educational outcomes, especially when teaching and learning styles are matched $(5,6)$. If a teacher 
believes the quote mentioned above - that a student will remember and hopefully understand more by reading, hearing, seeing, saying and teaching someone else - then teaching methods should be developed to include all of these activities in class.

One method that a teacher can undertake to maximise student learning is the jigsaw classroom method. This is a strategy in which students are required to learn through reading, hearing, seeing, talking over with others, and teaching someone else. The method was believed to be developed by Austin in 1971 (7) and was initially tried out on elementary students.

This paper discusses the experience I had when applying the jigsaw method to third-year dental students during a water fluoridation lecture. My inclass observations and the students' feelings about the session are presented.

\section{METHODS}

Pre-lecture preparation was necessary to ensure that the jigsaw activity ran smoothly. The students' name list was obtained from the Dean's office and students were divided into six jigsaw groups. This was done at an administrative level to ensure that the groups were diverse in terms of gender and ethnicity. The other reason was to reduce potential unfairness if students were allowed to choose their own groups. Each jigsaw group consisted of six students. The water fluoridation lecture content was divided into six different topics, and handouts on each topic were distributed to the students.

A week before the lecture was due, a letter was sent to each third-year student containing instructions on what they should expect in the upcoming water fluoridation lecture. The list of the groups was enclosed with the letter and the students were instructed to sit with their new group during the lecture. Each student in each group received a different handout material. For example, in one jigsaw group, student 1 received a handout on the benefits and effectiveness of water fluoridation, student 2 on fluoride mechanisms of action, student 3 on optimal fluoride levels, student 4 on the cost of fluoridation, and student 6 on the safety of water fluoridation. The students were advised to read their own handout thoroughly before attending class. No other instructions were given at that time.

On the lecture day, a normal 15 -minute lecture was given to introduce the topic of fluoridation to the class. Students were then instructed to break from their jigsaw group and meet other students who had identical handout materials. For example, students who received handout materials on the safety of fluoridation mete with the five other students who received the same notes. This group was called the expert group, and students were encouraged to step out of the class during this expert session. This is because on the yearly evaluation form, students often request that classes be held outside the classroom. Each member of the expert group was then asked to discuss what they had read in order to develop a deeper understanding of the topic. Once each expert group was satisfied with the knowledge that they had, they were then asked to meet with their respective jigsaw group. Each student was then requested to teach his or her own jigsaw group about their specialty.

Clear instructions were given before the students were asked to go to the next activity, for example, "I think you have grasped the concept of your own topic, now we will go to the next activity which is ....". I made myself available throughout the onehour session, but did not join any jigsaw group unless invited to clarify unresolved matters.

At the end of the class, students were asked to reflect upon the learning experience and to write down their feelings on the newly introduced teaching method.

\section{RESULTS}

This section is based on my own observations during class and the reflection essay that the students wrote. The short essay analysis consisted of a careful reading of the content for the purposes of understanding and exploring students' feelings towards the jigsaw method. There were 66 third-year students in the year. Of these, 50 students handed back their essay.

\section{In-class observation}

When the students were asked to move around in class during the expert session, I could sense resentment from their facial expressions and bodily movements. It took quite a while to get the experts to meet the other experts. Some students also disliked being asked to step out of the class, and a few students asked whether they could choose their own group as they did not feel comfortable with the other members of their jigsaw team.

During discussion among the experts, I could see that some students were not interested in being involved in the discussions, although many were intensely engrossed. After five minutes has passed, students who looked disinterested were told to pay extra attention as they would need to teach their speciality to their other jigsaw group members. Only then did they start to take interest in the discussion.

When the experts rejoined their jigsaw group, I could sense excitement among them. The students were eagerly teaching their friends and looked thrilled to be able to share their knowledge with their jigsaw group members. Plus, the session was not one way where only the expert talked - the other 
members were also seen giving their thoughts and comments in order to clarify certain areas.

\section{Reflective essay}

Two main feelings appeared in the students' short reflection essays: a positive attitude, and feelings of doubt and uncertainty towards the jigsaw method.

Almost all students expressed their enjoyment and satisfaction after experiencing the new learning environment. Most students said that the experience had been stimulating, fun and enriching.

"I felt very happy during this learning session. It kept me alert and awake, and I understand in depth on the topic"

Student 20

"This is the most interesting lecture in the Community Dentistry module. There was a lot of interaction among students... it made me learn and remember the topic ... I enjoyed it so much.

\section{Student 18}

"This is an effective way of learning ... very interactive ... it was absolute fun"

\section{Student 14}

"... maybe this is the only lecture session where I gave my full concentration and understood what I'm supposed to be learning"

Student 39

Students conveyed the benefits of the jigsaw method, and mentioned that learning through teaching and discussion enhanced their understanding of the topic, and that they were able to retain the information better. Four students specifically stated that the experience would improve their soft skills, which would be important in the future. One student wrote that since they were asked to discuss in small groups, he felt comfortable and did not feel shy or embarrassed.

"I can understand and remember the topics or subjects that I've taught my friends and I've learnt more by listening to my friend's explanation on the other subtopic"

Student 10

"It seems that I understood more on the topic when I teach my friends than when I get the information directly from the lecturer. I also learnt how to transfer the information from my point of view and understanding to my friends"
"... When the time comes when I need to give details on the subtopic, all I need to do is to remember who talked about it and I'm sure I can remember the subject matter"

Student 21

"This is a creative way to stimulate our minds and it can definitely improve our soft skill"

Student 42

However, three students were doubtful and uncertain about the quality and quantity of the material that they had received verbally from their friends. These students still preferred the traditional method of teaching through lectures. Two other students felt that the jigsaw session had been enriching, but that learning would be heightened if the lecturer took over at the end of the session and gave an overall conclusion on the subject. Two students were worried whether the information they received was sufficient for examination purposes.

"I prefer having a lecture than this session. During a lecture, the information that was conveyed by the lecturer to the students is similar for all. But during a jigsaw session some students can't manage to deliver all the information that they know"

Student 7

"One of the disadvantages of this method was that nothing was done to verify whether all information delivered is correct and valid"

Student 37

"I think the information received during group teaching is not enough. I wonder if it is sufficient for examination purposes?"

Student 31

Lastly, two students stated that it was time for the faculty to fully change the didactic teaching method to the jigsaw method.

"This type of activity should be used in all learning sessions. No more lecture sessions please as lectures are so boring"

Student 23

"If I have the power to advise the Dean, I'd ask him to make it compulsory for all lecturers to use this jigsaw strategy in all their teaching methods"

Student 17 


\section{DISCUSSION}

The aim of this paper was to share the jigsaw method with other dental educators and convey how students felt after the experience. There was no intention to make a comparison between the jigsaw method and traditional lecture methods or other teaching methodologies, nor to state which method is superior. It is hoped that by sharing teaching methods that are thought to be effective, educators can learn from each other and it can further diversify dental educators' teaching methods.

The predominant teaching method used in detal schools is the didactic lecture format, which is teacher-centred and students passively take in information provided by the lecturer. Students who are accustomed to this format are often frustrated when teaching styles change dramatically (8). Hence, it was predictable that students were dismayed when they were told that a 15-minute lecture was all that they were receiving that day and that they would need to work in groups for the rest of the session.

This resentment is similar to other schools where many students expressed resistance to group work. Cravener (9) stated that her nursing students' written responses showed that they were in the stages of denial and anger when asked to work in a group during class. Reid (10) studied language students from a variety of ethnic backgrounds and found that every background expressed a minor or negative preference for group work. However, students' resistance towards group work and active learning changed once they got into a group and started to learn from each other.

Having realised that they benefited greatly in terms of understanding the subject, most students expressed satisfaction with the jigsaw method. Cravener's (9) students' stages of denial and anger changed into acceptance by mid-term. Patel et al. (11) found that students who were in the pre-clinical stage of their medical degree favoured small group sessions and claimed that the sessions were the highlights of the year.

The unique thing about the jigsaw method is that it allows students to be in their comfort zone first, where they are able to interact and discuss with their colleagues who have the same information as them. The second part, which determines the success of student learning, requires the students to teach their other colleagues who do not have access to their handouts. Benware (12) believed that when people learn to teach, they learn more actively. He found that students who learn to teach are more intrinsically motivated and have higher conceptual learning scores than students who learn in order to be tested. Glynn et al. (13) demonstrated that when fifth-year medical students taught their second-year students, there was a high level of acceptability between the groups and positive comments about the learning environment, which is vital in effective teaching and learning.

Peer-assisted learning can be an efficient way of incorporating extra training that students find enjoyable and assess positively (14). Qualitative analysis has shown that both the students that teach others and the learner students benefited, and that there is a positive correlation with examination performance $(15,16)$. However, previous research usually utilised senior students to teach their juniors. In the jigsaw method, students in the same year teach each other. Students must therefore be made to understand that the only way they can complete the lecture objectively is by listening and teaching others. Group members must work together as a team to accomplish a common goal, with each person depending on all the others. Such "cooperation by design" facilitates interaction among all students in class, encourages listening, engagement and empathy, and leads students to value each other as contributors to their common task (17).

The main difference between the jigsaw method and other active teaching methods such as casebased and problem-based learning is that the facilitators in the jigsaw method are not required to be in immediate contact with the group, although they are available in the classroom at all times. The groups are free to discuss their subject matter without having the facilitator nearby to listen and give immediate feedback. This method suits Asian students, who do not ask questions or participate actively, and take a long time before they will speak in discussion groups (18). Ho et al. (18) did an experiment on Asian students where after a nearzero level of spontaneous participation in discussion groups, the teacher divided the discussion group into smaller subgroups and walked back and forth between the subgroups in the same classroom. The teacher found that spontaneous participation increased dramatically.

Khoo (19) argued that when students are being watched, they speak because they feel that they are being assessed. He also assumed that Asian students do not enough confidence to seek information independently without guidance from teachers. This was found in this study, where some students doubted whether they had received valid information from their peers and whether the information was sufficient for them to answer questions during examination. Some students requested that an overview of the subject be presented by the lecturer at the end of the class. Moffet (8) stated that although providing information is necessary during class time when content is complicated or confusing, lecturers should not spend valuable time re-teaching prerequisite content, and it is advisable to have 
suggested sources for review. Dentists are now expected to engage in lifelong learning, so they must have critical thinking, independent learning and evidence-based skills. These skills are best taught while they are in school.

This study only looked at students' perception and feeliings towards the jigsaw classroom in one cohort and at one point in time. It was also based on my observation as the sole classroom facilitator and analyser of their narrative essays, therefore bias in interpretation could have occurred. Various students have shown that learning improved $(17,20)$ or showed no difference $(21,22)$ when teachers used this method. Future students should follow dental students who receive only the normal lecture and another group that receive this active learning method and compare thier clinical and examination performance. Further study should also investigate whether the high level of memory retention claimed by students using this method is true.

\section{CONCLUSION}

Giving lectures in a lecture hall to a large audience is not the only method of teachig. Lecturers must take the initiative to learn and try other teaching methods and to mix and match them to maximise learning among students. In this study, the jigsaw method proved that learning in the classroom can be fun, educational and enriching.

\section{REFERENCES}

1. Murphy RJ, Gray SN, Straja SR, Bagert MC. Student learning perferences and teaching implications. J Dent Educ 2004; 68(8): 859-866.

2. Gibbs, G., Habeshaw, S. and Habeshaw, T. Improving student learning during lectures. Med Teach 1987; 9(1): 11-20.

3. Krueger PM ete al. To the point: Reviews in medical education teaching techniques. Am J Obstet Gynecol 2004; 191: 408-11.

4. Myers B. Beliefs of dental faculty and students about effective clinical teaching behaviour. J Dent Educ 1977; 41: 68-76.

5. Dunn RS, Dunn KJ. Learning styles/teaching styles: Should they ... Can they ... be matched? Educational Leadership 1979; 36: 238-44.

6. Fischer BB, Fischer L. Styles in teaching and learning. Educational Leadership 1979; 36: 245 51.
7. The Jigsaw classroom, Elliot Aronson, Official web site for Jigsaw Classroom method, website with instructions at: http://www.j1gsaw.org

8. Moffet B. The transition to active learning. A lived experience. Nurse Educator 1997; 22(4): 4447.

9. Cravener P. Promoting active learning in large lecture classes. Nurse Educator 1997; 22(3): 21 26.

10. Reid JM. The learning style preferences of ESL students. TESOL Quarterly 1987; 21:87-111.

11. Patel VL, Arocha JF, Branch T, Karlin DR. Relationship between small group problemsolving activity and lectures in health science curricula. J Dent Educ 2004; 68(10): 1058-1080.

12. Benware CA, Deci EL. Quality of learning with an active versus passive motivational set. Am Educ Res J 1984; 21:755-765.

13. Glynn LG, MacFarlane A, Kelly M, Cantillon, P, Murphy AW. Helping each other to learn - a process evaluation of peer-assisted learning. BMC Med Educ 2006; 6:18.

14. Field M, Burke JM, McAllister D, Lloyd DM. Peer-assisted learning: a novel approach to clinical skills for medical students. Med Educ 2007; 41:411-8.

15. Anderson R, Robins L, Fitzgerald J, Zweifler J. Fourth year students as small group leaders of first year students. Acad Med 1996; 71:793-4.

16. Schaffer JL, Wile MZ, Griggs RC. Students teaching students: a medical school peer tutorial programme. Med Educ 1990; 24: 336-43.

17. Aronson E, Blaney N, Stephen C, Sikes J, Snapp M. The Jigsaw Classroom. Sage Publications, Beverly Hills, CA 1978.

18. Ho DYF, Peng S; Chan FS. Authority and learning in Confucian-heritage education: a relational methodological analysis. In: Salili F, Chiu SY, eds. Multiple competencies and selfregulated learning: Implications for multicultural education, Greenwich, CT: Information Age Publishing 2001.

19. Khoo HE. Implementation of problem-based learning in Asian medical schools and students' perceptions of their experience. Med Educ 2003; 37: 401-9. 
20. Lucker GW, Rosenfield D, Sikes J, Aronson E. Performance in the interdependent classroom: A field study. Am Educ Res J 1976; 13: 115-123.

21. Moskowitz JM, Malvin JH, Schaeffer GA, Schaps E. Evaluation of a cooperative learning strategy. Improving College and University Teaching 1983; 32: 87-90.
22. Palmer J, Johnson JT. Jigsaw in a college classroom: Effects on student achievement and impact on student evaluations of teacher performance. Journal of Social Studies Research 1989; 13: 34-37. 